Jelena Šesnić

University of Zagreb

\title{
A Diasporic American Mirror for Late Socialist and Early Democratic Croatia
}

Taking as a starting point the eventfulness of 1989 — the fall of the Berlin Wall—as a historical break, the author contends that by virtue of historicist inscription, but also careful textual analysis, it could be argued that late-socialist literature in Croatia, especially in the genre of the travel narrative (real or imaginary), has been able to register, accumulate and project some of the preceding and successive shifts and breaks. It is in the travel narrative, as recently revived in postmodernist literary theory and conceived of as a para-ethnographic writing, that the discourses of self, other, identity, heteroglossia, translation, and representation find their full articulation. In particular, the article discusses these and related issues on the tentatively constituted corpus of mid-to-late 1980s travel narratives of Croats in the United States by Božica Jelušić, Neda Miranda Blažević, and Josip Novakovich. By conjoining these writers the article offers a new interpretative framework that aims to both transnationalize the reception of these writers and their work, and point to indicative array of hetero-images of America that at the time spawned specific auto-images of late socialist Croatian and Yugoslav societies thus producing an emergent vocabulary of historical change.

Key words: travel narrative, 1980s Croatia, late socialism, Božica Jelušić, Neda Miranda Blažević, Josip Novakovich, hetero-image, auto-image

In the studies of the communist bloc before 1989, the case of Yugoslavia enjoyed what was in some ways a specific status since the system obviously was neither a replica of the Soviet model of management nor a functioning Western-style democracy. ${ }^{1}$ The specificities observable in the Yugoslav sys-

1 The essay is part of research conducted in the project "A Cultural History of Capitalism: Britain, America, Croatia" funded by the Croatian Scientific Foundation (HRZZ-1543). 
tem of economic and political management were, justifiably or not, touted as singularly apposite to the state's peculiar constitution (being a federated republic) and were often ascribed to the inner-directed need of its multi-ethnic population, rather than the result of the single (communist) party's system of bureaucratic decision-making. I will put aside the debates pertaining to the nature of the League of Communists' rule in the second (i.e., communist and socialist) Yugoslavia in its 45-year long history, but will simply note that certain inner-directed and outside factors (principally, post-WW II alignments and Cold War exigencies) played a key role in what Vesna Drapac has recently termed the process of "constructing Yugoslavia" in her eponymous study (Drapac). In this presentation, my aim is rather to outline how the dense and continuing links between the United States and Croatia/ Yugoslavia were presented by the several representative Croatian and Croatian American writers in the period targeted by this year's workshop, the nineteen-eighties topped by the watershed event of 1989 .

That the revolution of 1989 deserves such a moniker is evident from its sweep, popular appeal, mass participation, and, not least important, the change that it propelled into motion by occasioning the swift (and unanticipated) collapse of the communist regimes and the attendant socialist economic systems in Europe. ${ }^{2}$ Such a scope calls for a perspective based on the transnational view, precisely insofar as it may help register one of the key threads in the dissolution of the Yugoslav federation - the end of the Cold War arrangements reflected in the changing stakes that were put on the fate of Yugoslavia, all other things being equal (that is, bypassing for now the discussion of the intersection and impact of a host of domestic Yugoslav developments brewing for some time and coming to boil at the time of major global

2 As pointed out by Timothy Garton Ash, 1989 is the year that ended the short 20th century, especially if one considers the fall of the Berlin Wall in conjunction with the unification of Germany and the dissolution of the Soviet Union. But his statement about the need for a comprehensive, synthetic history of 1989 that yet remains to be written is both a testament to the slow motion of history as well as to historians' laggardness. 
and European realignments). ${ }^{3}$ (A note on usage: Although for the sake of economy I will occasionally use the terms "socialist" and "communist" intermittently, in other contexts their usage and implications ought to be differentiated. Suffice it to say that in most discussions, where the distinction is made, the socialist stands for the economic system and its derivations, while the [less popular and certainly less protean] communist stands to mark the political, statist, and power-based elements of the system: thus Yugoslavia was a communist regime run by a single party, whereas it operated a socialist economy.) $)^{4}$

These observations of a political nature will in the remainder of this presentation be supplemented by the main interest of my analysis, which is largely cultural and literary. Specifically, I will be asking if the Yugoslav/ Croatian encounter with America during the 1980s indicated a shift that could be termed "historical," and specifically linked to the end of the Cold War, the demise of communism, and, consequently, the end of Yugoslavia. In asking such a question, I am implying the particular epistemological acuteness of literary discourse, since, ideally, it contains multiple, varied and contradictory renderings of the context that gives rise to it. As such, my discussion will concern the works of three authors, in chronological order: Božica Jelušićs Okrhak kontinenta (A Sliver of the Continent, 1988), Neda Miranda Blažević’s Američka predigra (American Interlude, 1989), and Josip Novakovich's Apricots from Chernobyl (1995), Plum Brandy (2003), and Shopping for a Better Country (2012). I have deliberately chosen these works since they share a generic identity (the texts being travelogues, real or fictional or some variation thereof, as in Novakovich), while the situations that occasioned the creation of these texts derived from their authors' act of travelling from Croatia/ Yugo-

3 For this I refer the reader to a competent and informative overview in Sabrina Ramet's study Balkan Babel, which conveniently covers both domestic and external factors.

4 For more on the nature of European and world communism, cf. Koenen; for a comprehensive study of the concept and practice of socialism, cf. Verdery. Ideally, these two historical phenomena should be studied in conjuction, as indeed they historically arose together, rather than in isolation. 
slavia to the USA and back. In the case of Blažević's account, however, the approach has to be further attuned to the fact that hers is a case of a fictional travelogue (autobiographical novel, intellectual diary, etc.) rather closely based on the author's experience as a Fulbright scholar spending a year in the United States. Blažević's and Novakovich's biographies further suggest a diasporic node of emergence. Let me also note that Blažević's and Jelušićs texts are written in Croatian, while Novakovich's are available in English (with the proviso that some of these texts have been translated into Croatian). It seems, however, that the texts share a similar repertoire both of auto-images of the late communist society and hetero-images spawned by America to the extent that would encourage their reading alongside one another. Furthermore, as a general backdrop for reading and understanding these texts, it could be argued, in line with the contributors of the collection of essays on the 1980s in socialist Croatia, that the end of the decade witnessed the acceleration of history, in a way that much of it could not be anticipated or managed by the members of the socialist cultural elite to the extent that they, wittingly or not, contributed to the course of events. Moreover, the picture of Croatian culture in the 1980s must be placed in the context of the "decadence," only partly attributable to the not-very-uplifting political context (cf. Jakovina 13-34) and partly a result of the steady adoption of late-capitalist and postmodernist aesthetic notions finding their way into all channels of cultural expression from literature to architecture, from fashion to sports (cf. Kostelnik and Vukić).

That the texts singled out for the discussion are travelogues is not mere happenstance but reflects the long-standing status of the travel narrative as a source of auto-images by way of focusing on hetero-images, to use the vocabulary of imagology (cf. Dukić 5-22). In other words, I contend that, by looking into the production of images generated by the Croatian authors' experience of the United States in the 1980s, we can simultaneously glean their attitude toward their home country, refracted through a diasporic or migrant's glass. The genre of travel narrative has served to highlight the issues in postmodernity pertaining to multiple theories of identities, nationhood, self, and other, while recently, Debbie Lisle has understandably emphasized the genre's con- 
tinuing political and social valence-the statements about another country are illustrative of one's own society, its make-up and its priorities (1-23). A similar intention is to be argued about the three travelogues produced by the Croats engulfed by America in the 1980s. The cultural potency ascribed to the travelogue genre gives rise to the assumption that the writers' encounter with America transposed into text will carry the marks of the aforementioned process of translation from the other to the self, meaning that the visions of America should be read also as views of late socialist Croatian and Yugoslav societies.

Furthermore, in cultural theory there has recently been a renewed interest for what James Clifford calls para-ethnographic genres, among which he includes travel literature (alongside oral history, the non-fiction novel, new journalism, and the documentary film) (24 n. 3). Being part of an innovative field of knowledge production in a globally intersecting world, genres such as the travel narrative partake of different models of authority: realist mode, experiential, interpretive, dialogical, and polyphonic (Clifford 53), crisscrossing in a single text. Not surprisingly, in his elaboration of recent developments in ethnography, Clifford seizes upon Mikhail Bakhtin's concept of "heteroglossia," the meaning of which is taken here to encompass not only the relationships between different languages, registers, and discourses, but also different cultures and subcultures (Clifford 23). What is further interesting to note about the specific implications of heteroglossia in this context is how "crucial [it is] for different peoples to form complex concrete images of one another, as well as of the relationships of knowledge and power that connect them" (ibid.). Taken in this manner, Bakhtin's concept becomes not only a harbinger of global cultural communication and interconnectedness but a feature of an interaction (between peoples, cultures, etc.) marked by the circulation of knowledge and the effects of power. This added complexity of (already complex) heteroglossia is even more in evidence in Pratt's (2008) unequivocal reading of the travel narrative as textualization of, in turn, the politics of colonialism and, later, of anti- and post-colonial imaginaries. Pratt's equivalent of Bakhtin's somewhat elusive, since immaterial and discursive, 
spaces of dialogue, heteroglossia, and polyphony is a spatial metaphor of the "contact zone" (Pratt 7), a construct attuned to the worldly questions of power, knowledge, and representation. These approaches together with their attendant concepts might be fruitfully used to account for these heteroglossic texts arising in a contact zone between Croatia, Yugoslavia, and the United States and spanning Cold War and post-Cold War imaginaries.

My next hypothesis does not arise self-intuitively from the texts at hand but is a result of retroactive inscription which looks in this array of texts for signs of what Raymond Williams calls "a structure of feeling," such that demonstrates an interface of "residual" and "emergent" values, a position of historicist ascription of meaning. As Stephen Shapiro notes in a somewhat different context, "structure of feeling" refers to "the mediated representation of experience within moments of historical transition" (27). In other words, I will be looking for hints and indications of extant "semantic figurations" (corresponding to the residual culture) that struggle to enunciate an incipient sense of change and transformation for which subjects as yet lack vocabulary and "communicative forms" (corresponding to the emergent culture). ${ }^{5}$ It is obvious that this kind of hindsight becomes possible precisely by assigning to the fall of communism in 1989 an eventful and historic significance. ${ }^{6}$

It goes without a saying that these writers-Jelušić, Blažević, and Novakovich-do not invent wholesale an America that bears no relation to the extant images of the country circulated in Yugoslavia, whether in the sphere of popular culture (especially in cinema and music, but also on TV, later on) or in the domain of the official political discourse that, at least from the early

5 A longer quote from Shapiro, using Williams, reads as follows: “...Williams used structures of feeling to describe the 'articulation of an area of experience which lies beyond' currently available semantic figurations. As groups experience the whirlwind of change that is difficult to describe, they often resort to and reside within 'certain [dominant] modes, conventions of expression' that are only 'approximations or substitutions for their own structure of feeling"' (28).

6 This is precisely the position of the aformentioned Garton Ash and Koenen. This view is nicely illustrated also in this collection by Stipe Grgas's contribution. 
1950s and the strengthening of relations between the regime in Yugoslavia and the United States, would be obliged to find a way of mediating capitalist (and imperialist) America to its citizens. ${ }^{7}$ As an early example of a cultural portrait of America spiced with political hints, let us look at traveler's sketches by Vladimir Dedijer, who visited the United States in the capacity of a Yugoslav envoy to the United Nations conference in San Francisco from April to July 1945 and whose observations might just as well be one of the earliest reports on the United States for the Yugoslav audience (his booklet came out in October 1945). In his Beleške iz Amerike (Notes from America), Dedijer is mostly concerned with the American cultural industry: the press, radio, and Hollywood, which he correctly perceives as pillars of mass culture. Since my presentation is focused on imagery, I would like to point to the chapters where Dedijer's attention is captured by a certain type of Hollywood production pertaining to the Popular/Cultural Front (Denning 2010). As an illustration of Dedijer's critical thrust, let us consider his take on the movie The Little Foxes, starring Bette Davis and based on Lillian Hellman's play (playwright was allegedly a CP card-carrying member). There, as Dedijer contends, on an example of a planter's family the film illustrates the intrusion of capitalism into the backward feudal parts of the U.S. South at the century's end (175; all translations mine). ${ }^{8}$ Given Dedijer's political predilections, it is not surprising that the other movie featured in his account tackles another problem of the U.S. South-this time it is the "Negro" question partly as it stood presented in the war film Negro Soldier (175). This Hollywood

7 I cannot refrain from enlisting an example from Nedjeljko Fabrio's postmodernist neo-historical novel Vježbanje života (Exercising Life, 1985), in which the narrator, assuming the point of view of his adolescent characters in Rijeka, barely won over from Italy after Yugoslavia's victory in World War II, registers the youth's exasperation at the unending flood of Soviet war and propaganda films, which, however, abruptly ended in 1948 and was soon replaced by Esther Williams's feature films (366). The Williams phenomenon is mentioned also by Crnković (158). It goes without saying that other forms of U.S. assistance to Yugoslavia followed a similar course.

8 Davis was nominated for an Academy Award for the leading role in the film but, as may be presumed, not for the reasons stated by Dedijer. 
interlude then gives rise to Dedijer's elaborate comments on the social and economic position of American blacks, accompanied by illustrations, graphs, and data from learned books on the problem (e.g., the then current Myrdal study) which paints a not-too-flattering image of the state of civil rights in America (the reader was invited to savor the fact that Yugoslavia certainly had no such problems at the time).

Dedijer tops the sociologically imbued view of the American cinema by recounting his encounter with Charlie Chaplin. His admiration for the popular and "progressive" artist (210) who embodies a little man (203) is second only to his lionizing of Chaplin as an independent artist able to set up his own production company and start producing independent films. Chaplin is at times a fighter for social justice and a self-identified "socialist," as he asserts in his conversation with Dedijer (209), and on occasion a businessman with enough capital not to bow to Hollywood and big banks (204). The principal thrust of Dedijer's take on America offers a mix of admiration for the "progressive" aspects of America that he encounters across the country (from Yugoslav emigrants to well-disposed U.S. citizens admiring Yugoslavia and its recent victory in the war) and his implications that the democratic standards of the country are in some ways lacking concerning the freedom of the press, of speech, and of artistic creation (certainly a peculiar observation to make in historical perspective). ${ }^{9}$

At the next stage, back to my designated period of study, my analysis will attempt to show how these three accounts placed on a timeline of the late 1980s and early 1990s indicate the impending and uncontainable historical changes overtaking Europe, rather than the United States as such. Our Croatian (academic) travelers in America (Jelušić and Blaževićs's fictional coun-

9 It should be pointed out that Dedijer's views are used here as an early illustration of relations between communist Yugoslavia and the United States. Other travelers from this period, to mention Bogdan Raditsa or Ivan Meštrović—both of whom took a one-way ticket to the States-would produce quite a different account. The point is that their hetero-images of America and resultant auto-images of Yugoslavia, unlike Dedijer's, would be prevented from being circulated in Yugoslavia. 
terpart), have already been seasoned in American ways given the manifold ties between the two countries-in particular due to the considerable body of emigrants from Croatia in particular, but other parts of Yugoslavia as well, in the States. ${ }^{10}$

The other factor is the mostly uninterrupted travelling between the two countries (this fact did not hold for the countries in the Eastern bloc), here cast in the form of a scholarship residence or an academic journey, and thus additionally imbued with life-changing importance that can easily be translated into a travelogue form as a variant of the quest narrative, which is always in part self-discovery. In other words, the Croatian academic travelers are affected and changed by their sojourn in the States, as they make clear in their accounts. ${ }^{11}$ The cases of Božica Jelušić and Neda Miranda Blažević (the latter a rising star of women's writing in late socialist Yugoslavia) point to a constant interest in and occasionally fascination with the United States and its various aspects - some of them tied to liberal capitalism, others only fractionally related to it-and testify to the continuing need to represent the country and translate its less comprehensible aspects to the domestic audience, as pointed out by Gordana Crnković (159). If above I have issued a warning against singling out the case of Yugoslavia and the ties with the U.S.A. proceeding from its diaspora, here I have to qualify that statement by suggesting that the 1989 event did not portend such a dramatic cultural break

10 I hasten to add, given my transnational focus, that this connectivity is not to be seen in exclusive, not to say exceptionalist, terms since other countries in the Eastern bloc also boasted of considerable U.S. diasporas (witness Poland, Czechoslovakia, Hungary) and to the extent possible kept up either sanctioned or underground ties with them. This is the subject of a two-volume study of parallel experiences of exile in Eastern and Central Europe during the Cold War, which also includes the case of Croatia (Mazurkiewicz).

11 I have room here only to hint at the possible cultural and political importance of a continuing Fulbright and other exchange programs in existence between the former Yugoslavia (later on Croatia) and the United States; the consideration of these programs' long-term effects and their manifold impact makes for an interesting segment of the cultural history of the Cold War and its aftermath and would add to the fuller consideration of American cultural diplomacy. Let me just add that the Fulbright Program was initiated in Yugoslavia in 1964; in Croatia in 1992. Cf. Belair. 
for Yugoslavia as it did for other countries of the socialist bloc, for which the reception of American popular culture could hence proceed unimpeded, free of the taint of regional or cultural "polarization" (Ramet and Crnković 6).

It is certainly correct to note that the reception of some aspects of U.S. culture in the Croatian/ Yugoslav context was constant, largely unobstructed and very comprehensive, just as we have to contend with Stjepan Meštrović's succinct remark suggesting that the consumption of American artefacts or products did not imply at the same time the adoption of the country's political ways, let alone of its governing system (160). Jelušić and Blažević show how a socialist subject coming from Croatia experiences several parts of the huge country, virtually a continent, in terms of this inherent dualism: affinity and closeness to some aspects of American culture (indicators of American high and pop culture) on one hand and distance and obliviousness on the other. This skillful varying of distance and closeness, of the familiar and the strange, underlie a travel narrative and simultaneously highlight the nature of the genre based on national imagology, to paraphrase Crnković (159). The situation that gives rise to both Jelušićs's and Blaževićs's text is a specific case of intercultural communication; in the words of Crnković, it is a politicized situation of a "cultural exchange program" (159), particularly the long-standing Fulbright Program. It bears repeating, the phenomenal success and impact of the program aside, that it began as a Cold War initiative intending to weave the cultural and the political strands in a sophisticated attempt of the various U.S. state agencies to make their appeal to hearts and minds on a global scale. Needless to say, the cultural strategy works in manifold ways and can hardly be contained by one direction only (cf. Rugh).

Geography-wise, the two texts cover a wide swath indeed: Jelušić takes us to the Emerald City (Seattle) and Canada in the last stage of her stay, with an episode in San Francisco exuding a somewhat nebulous quality. In Blažević's case, the Fulbrighter and her partner, a sculptor, begin their sojourn in the Mid-West during the winter semester of 1984, while in the summer semester of 1985 we follow them to New York City. Jelušićs initial impressions of America during her one-semester stay in 1986/1987 as a Fulbright 
fellow at the University of Washington, Department of Slavic Languages and Literature will only deepen in her subsequent notes. Originally, America portends spirituality, offers a sense of immense space, and abounds in natural features and social phenomena. This glamorous perspective is later undercut in her other sketches by images of indescribable poverty and desolation witnessed in downtown Seattle and on a tourist visit to an Indian reservation in Washington State. Her conflicting emotions at America's contradictions are worked through by a strong symbolic presence of Indians in her text: it is their spirituality, as well as those of several Eastern traditions-Tibetan and Buddhist - that sustain her presence in and accommodation to America, as she claims that her travel replicates "Black Elk's spiritual journey" (11; all translations mine). This Indian presence can hardly afford to remain stuck in mythological, symbolic and poetic frames since it is used subsequently by Jelušić to articulate a most strenuous and trenchant criticism of American society, consisting mostly in registering the gap between reality and "mimicry" (20), between the authentic and the fake. For instance, she will note the state's obsession with ecology that simultaneously fails to include the Indian inhabitants and is predicated on their containment in reservations, the most un-ecological of places.

America, however, is not reducible to a single referent, especially since its otherness is often best conveyed when encapsulated in an emigrant'sthe everlasting other's-experience. An inserted story of a family of political exiles from Tibet that fascinates Jelušić serves to render an image of America that might reconcile the contrasting images of heaven and hell, marking Jelušićs impression of a continent that masquerades as a country. The fact that the Tibetan displacement is caused by political factors is not dwelt upon by Jelušić, but continues to linger in the reader's mind as she considers the previous case of disenfranchised Indians, the polar opposite of the empowered Tibetan family that thrives culturally, economically, and familially upon reaching America.

Other hetero-images are contained in Jelušićs encounters with "our" people in the States, where she reiterates the story of mobility by underwrit- 
ing the immigrants' experience and so perpetuates, albeit in a subdued form, the narrative of economic opportunity and success. Another parallel, however, is more conspicuous in the text, especially in the context of the impending dissolution of the multi-ethnic state of Yugoslavia: the academic spaces and locations visited by Jelušić seem to exude an aura of interethnic harmony and co-operation that obviate every mention of ethnic origin and roots and are simply rendered obsolete by the vastness and variety of the American context (32-33). The acculturating engine of the U.S. liberal sphere and the society of abundance, affordable work, and consumption (for all but the Indians and the homeless paupers in downtown Seattle) renders all identitarian markers superfluous. From an intervening historical distance, this shows why and how it was possible that, due to the absence of these factors, the ethnic elements in Yugoslavia were gaining pre-eminence precisely in this period.

Other indicative observations follow from cultural differences that are embedded in different political systems. At one point, Jelušić registers the American mania for privacy: "The rule here is to mind your own business. Privacy, Holy Privacy is absolutely respected" (36). This is not simply a sociological quirk but carries also certain political connotations, since a communist society in comparison was not likely to put such a premium on the bourgeois concept of privacy. The ubiquity of technology and the commodity culture inform the daily life and a host of cultural practices in the States, such as the rampant use of (portable) telephones: "Telephone equalizes people, erases classes, differences and complexes," Jelušić suggestively proposes in her ambivalent take on the benefits of a consumer society (37).

Having already identified the historical burden accruing to the genre of travel, I deem it necessary to broaden my claim by pointing to Jelušićs clear admission to the genre's colonial and imperialist past. In the final section of the travelogue, Jelušić trots off to Canada for another guest visit. Perhaps not surprisingly, her experience of Canada is enframed by an extended quotation (101-5) from none other than James Cook's (the discoverer's) log, which goes to illustrate the embededness of the travel narrative in the age of discovery, colonization and imperial projects, as shown by Pratt (15-36). Howev- 
er, this realization further poses the question of the implications of Jelušić's textual authority and begs the question of whether her rendering of America is a distant cousin to the discoverers' grand narratives of the beginning. To answer this question in the negative, we ought to go to an earlier moment in the text when Jelušić demurs at the pretentious and grandiose statue of one of the earliest Franciscan Spanish missionaries in California, Junipero Serra (77). Certainly, her visit — riddled with incomprehension, cultural misgivings and open-ended conclusions - make Jelušićs story join ranks of textual accounts of the conquest of America by travel but does so in a way that both contributes to and deviates from the extant tradition of travelogues featuring America.

Another way Jelušić manages to evade the inexorable logic inscribed in the genre is that, throughout the text, she holds on to her outsider position, earned also by her different social and cultural credentials accrued by living in a socialist society, while largely avoiding, however, any political reference or insinuation and using this distanced perspective to produce a complex, ambivalent and engrossing vision of the United States. The final product is far from being an exhaustive report either on the United States or, even less so, on Yugoslavia but forms a patchwork, a sampling of images, narratives, individuals, locations, and impressions. Moreover, in her concluding remarks Jelušić reflects somewhat ironically on the metaphors that undergirded her travel; now it is not just the spiritual experiment in line with Black Elk's journey but also its opposite, California Gold Rush. Both strands intersect in Jelušićs multilayered experience of America. Also, Jelušićs writing is not a simple and direct rendering of her travelling experiences but a postmodernist artefact that ingests other cultural texts in the process of meaning-making. Thus, when she doubts that the transcontinental journey has indeed made her more enlightened (120), the reader hears the echo of Henry David Thoreau's dismissal of the travel fashion overtaking his compatriots as he facetiously calls for travelling widely in Concord, as he himself has done (Thoreau, "Economy"). In the same vein, at the very end of her journey, Jelušić offers the same deflating comment. Laced with seemingly frivolous, apolitical, and feminine concerns, 
her travelogue evinces the postmodern quality that situates it more specifically within feminist and, more innocuously, women's prose (itself an interesting development in late socialism); therefore, Jelušićs unpretentious and almost self-deprecating but also facetious title of a travelogue is "a patchwork to remember her by." Given that the period was heading towards the late 1980s, the decadent years that supervised the dissolution of the political, economic, and social base of Yugoslavia, it is worth observing how Jelušićs spunky text reflected those dynamic and uncontainable years.

Jelušićs intimate yet ironic and multifaceted perspective of America carries over into Blažević's text, also marked by a host of postmodernist techniques, in addition to being inserted into the current women's writing of the period (cf. Pogačnik 98). Blažević’s text, Američka predigra, is more layered and more ambitious in its conception than Jelušićs, attempting to combine an array of generic molds: novel, travel narrative, diary, and essay. Also, the device of framing stories is an important narrative strategy in Blažević's semi-fictional and semi-autobiographical travel narrative of her one-year Fulbright scholarship in the States, before she moved there in the early 1990s. Her experiences during the first semester, out of the two spanned by her Fulbright grant, are quite effectively contained in the the book's many intertextual references, its allusions to American pop-culture artefacts, and its largely deft handling of potentially awkward cultural situations - there is a feeling of cultural competence, only here and there riddled with faint nostalgia or marred by comparisons that exude a slight political feel. As I have suggested elsewhere in my reading of some aspects of Blažević’s hybrid text (Šesnić, forthcoming), the machinery of Cold War identifications has no way to distinguish among various socialist subjects that have washed up on the American shore; consequently, they are all swallowed up by the designation "Eastern European," with all the attendant significations that this category entails. This conflation, however, is not seen as an erasure of identity (at least not primarily so) on the part of the narrator, since the process happens against the backdrop of the layered, incessant, and unstoppable machinery of Americanization that is at work everywhere around her. Her colleagues, her students, and the native 
Indians have all been caught up in the process of becoming American and relinquishing something in return (Crnković discusses a similar process of conflation on the example of Dubravka Ugrešićs text about her U.S. experiences; cf. 161-64).

The culturally homogeneous space of the Midwest is deceptively simple for the narrator's initial embrace of America, but the stakes escalate once the stability and uniformity of the region is replaced by the fleetingness of New York City, the scene of the narrator's major psychological crisis bearing complex roots. Even if in the Midwest she was able to retain hold on her lifeas shown by her externalization of her thoughts, emotions, and reactions to her surroundings, which often took the form of interesting intercultural exchanges-in the second part of her stay, the external world no longer plays any role; it has vanished almost completely, supplanted by the coordinates of the fantastic, made-up world conjured up in the novel that she is composing in the city. The theme and structure of this novel-within-a-novel, recalling the trope of myse-en-abyme, should give us some indications of the reason for her flight inward.

Blaževićs primary intention is certainly not to launch a critique of the communist regime in Yugoslavia once she gets to the United States; she allows, however, a polyphony of voices to place the events in mid-eighties Yugoslavia in a critical perspective. On one hand, she makes clear that geographic and temporal distance skews the perception, since nostalgia is wont to play with our memories. An affectively laden perspective ranges from an invidious stance (considering Yugoslavia in terms of politics) to an affirmative one carrying personal and familial overtones. However, in an interesting displacement, the voices from home, the letters written to the Fulbrighters by their parents and family, paint an image of the Yugoslav plight in the 1980s: the crumbling economy, the inflation, the ubiquitous electricity shortages, the price hikes for "luxuries" such as tram tickets, meat, and coffee (65; translations mine), and, amidst all those measures of the economic stabilization program, the signs of further liberalization (for those that can afford them at the time): "the deposit for travelling abroad has been waved, as well as tokens 
for gas" (127).

As already mentioned, the narrator's wavering position is reflected in the confusion that her identity causes for her hosts: she is placed in the same bag as other East European dissidents, as when she is hosted at a literary event together with her illustrious counterparts from Poland and Czechoslovakia (such as Milosz and Skvorecky). The narrator plays along with this identity mix-up that is barely registered on the vast American canvass. When she gets to Columbia University at the beginning of her semester in New York in order to meet with her academic advisor, he is polite but vaguely lost in the variety of distinctions (political, linguistic, national, historical) that in the American academic context are simply dysfunctional, as the narrator wryly notes (122).

Blažević is fully aware of the ironic potential of the multiple identities that her alter-ego is made to embody in America, turning this identity confusion into an occasion for her art. In the last section of the novel, the embedded story presents yet another identity switch. The last part of the text is a fictionalizaton of the narrator's "real" memory (107-8) — that of the Czechoslovak residents temporarily grounded in Yugoslavia at the time of the Prague upheaval of 1968. Getting to know one of the young Czechs stranded in Zagreb awaiting the denouement in his country, the narrator belatedly (i.e., traumatically, by deferral) uses this memory to construct a fictional account of his family and their fate in the turmoil of the foiled liberalization movement. It is certainly intriguing to think what this yet another displacement- held in check by additional narrative framing - is likely to suggest about the political implication of Blaževićs layered text. I would like to suggest two readings of this deferred (and fictionalized) memory. One is that Blažević was not able to carry out this exercise in memory back in Yugoslavia. Consequently, and this is my second contention, it is her arrival in America-the space that both liberates and misrecognizes her-that offers a backdrop against which to set this sharply accentuated event. As in Jelušić's case, the stream of hetero-images pouring on the narrator as she collides with the American world sets in motion a train of auto-images leading to a crisis - of memory and the self, and by implication, of the idea of the society that the traveler came from. 
Over the years, Josip Novakovich has faithfully and uncannily traced the now residual elements of socialist/ communist system made all the more plastic against the ambivalent screen provided by his experiences as an immigrant in America, where he arrived in 1976. In order to briefly illustrate my points, I will examine his works in a longer temporal arc extending from his 1995 collection Apricots from Chernobyl to the essay collection Plum Brandy (2002) to his latest book of creative non-fiction Shopping for a Better Country (2012). Throughout my reading I will focus on the specific generic structures pertaining to the travel narrative and its derivations (tourism, emigration, exile), as well as showcase Novakovich's concern with the historical implications and reverberations of the interface of socialism and capitalism, East and West, autocracy and democracy.

Documentarism, oral history, memoirs, (auto)biographies, and similar genres have contributed to the burgeoning memory culture and, soon enough, memory industry as a result of the confluence of factors in the 1980s and 1990s (cf. Erll 7 - 9). That being the case, we ought to pose the question of the content of Novakovich's memory exercise, each time jogged by the experience of travel and mobility be it by his family members in different generations or by himself. Travel is indeed for Novakovich an existential itch, such that enables and sustains the memory process riddled with postmodern irony: "Whether travel made any epistemological sense, though, didn't matter; we were in the middle of it" $(P B, 105)$, he says about a journalist assignment in Croatia in 1997. Similar apprehension haunts the following exchange: "a Hungarian woman of letters, Sára Karig, who had spent six years in a Siberian camp, answered my question as to why she didn't write travelogues with, 'I don't even understand Budapest, where I've lived for fifty years. Why should I pretend that I understand Istanbul?"' $(P B, 105)$. The subjective and intensely personal perspective is apparently all there is and yet is the backbone of one's historical experience, as Novakovich shows. Let us inquire about what kind of history of late socialism Novakovich offers in his pieces.

Novakovich's travels are of an ambivalent nature, as they are driven by academic, existentialist, or political reasons. The author indulges in a reflex- 
ive move to attach his creative impulse to the urge for mobility, travel, and internal exile. The motif of spiritual exile is sounded early on in the memoirist section of his hybrid text Plum Brandy. In communist Yugoslavia, the young Novakovich feels oppressed by several intersecting systems: that of the dictatorship of the proletariat and labor, that of the ardent Baptist minority (itself molested by communist revolutionary atheism), and that of his patriarchal family - his father, a hard-working and entrepreneurial Baptist and owner of a private business, is an anomaly in the socialist country.

This narrative position Novakovich retains and varies in all his works, fictional and non-fictional. In Apricots from Chernobyl, his early collection of creative non-fiction, his time frame is more expansive than is the case for either Jelušić or Blažević, extending from the 1970s (and his first encounters with America as a new arrival) to the early 1990s - the collapse of Yugoslavia and the beginning of the war in Croatia. This extended temporality certainly provides a solid view of the cultural dynamics as an interplay of the residual and the emergent structures of feeling. Novakovich's engagement with America is from the first strongly colored by the official communist propaganda so that his narrator, a loyal citizen of Yugoslavia, experiences America as fiction, myth, a powerful stereotype even, which is ironically undercut by his fervent yearning to emigrate there (Apricots, 19). Emigration, which for him is neither a traumatic breach with the old country nor a matter of economic survival, turns his position into that of the self-imposed "exile" (Apricots, 22). This exilic position could be ascribed to the cultural paradigm that regulates the exchange and dynamics between Eastern and Western bloc, where Yugoslavia figures as a militarized stronghold carefully policing its borders, so that every border crossing is potentially dangerous (Apricots, 20, 21). On the other hand, exile here must also be understood as an existential condition of writing and creativity in which case borders are seen "not as obstacles but as thresholds to imagined freedom" (Apricots, 27). His identity as a writer hinges on the situation of mobility (also as an exile) that literally enables him to write or obtain a prestigious writer's grant won through his dubious exile status and desirable geographic origin. 
These issues are continued in Plum Brandy, Novakovich's next collection of creative non-fiction, a border genre favored by the writer that enables him to mix "travel stories, memoirs, reflections and portraits" $(P B, 12)$. I will mostly focus on the first section of the collection, in which Novakovich covers the period relevant for my present argument: the late socialist years. In this section I will show how a transnationalized perspective and a diasporic node of observation offer another take on the history of Yugoslavia, "with the place and the atmosphere dominating the stories" $(P B, 12)$. What begins as an exercise in memory, and thus credits and evokes the memory culture of the 1980s and 1990s, ends with the commemoration of an event, 9/11, which then arguably brings other interests to the fore, displacing the culture of memory.

Novakovich's longer historical arc turns him into a chronicler of the latter days of communism and Yugoslavia in the capacity of a witness; his envisaged Anglophone audience requires a transnational perspective that must eschew a one-sided view; his own wavering status-always in between and in the process of "shopping" for another country-turn him into a sober and wry commentator of both American and Croatian pre- and post-1989 developments. Also, given his American point of reference, the mold he works within is that of the Cold War, which as an international perspective is likely to put different premiums on several facts of Yugoslav history and the state's break-up.

Family memoirs are Novakovich's other favorite form (besides travelogue) intertwined with his vision of the Cold War and post-Cold War alignments. The discourse of memory, especially such that extends across several generations, serves as undertow to the forward thrust of the narrative of mobility so that it continuously tugs at it, pulls it back, or makes it turn in circles as the narrator tries to take stock of historical changes. Unlike Jelušić, whose discourse is "presentist" and immediately relating to the events she describes, allowing for the transposition of experience to proceed with no great temporal delay, Novakovich's slow-paced, circular, and self-reflexive style strives to accomplish in the world of text what in the historical world was no lon- 
ger possible: the meeting of East and West (here his approach approximates that of Blažević). Since these two then polar opposites do indeed converge in the history of the transatlantic mobility of five generations of Novakovich's family (on his mother's side; $P B, 171-72$ ), one could surmise that this (fortuitous) convergence forms the axis of Novakovich's narrative agenda that finds a nice summation even in his most recent collection, Shopping for a Better Country, where he circles around his favorite themes (temporality, mobility, identity, and art). His art, moreover, derives from and feeds upon an act of memorializing, most conspicuously his dead parents, as when he states: "My father's death gave me an impetus to write" (Shopping, 23). The circularity and uncanny repetitiveness of his narrative discourse (you never visit the same place twice) constitute a specific mnemonic quality marking Novakovich's entire work: "The question of exile and national identity can't cease for me" (Shopping, 13).

The author's vision of America, and retroactive vision of Croatia, that feeds upon his experience in emigration, is both individual and generic. It is individual insofar as the stories in several collections are in dialogue with one another, trying to weave the narrative of several generations of his family in their transatlantic migrations and return migrations. It is generic, since the experience is by now almost a standing motif in a range of texts, literary or historiographic, recounting the experience of the turn of the century (19th to 20th), the Great Migration, of which Novakovich's family on his mother's side was part: "My quest for roots here [Cleveland, U.S.A.] was matrilineal" $(P B, 172)$. The family arrangements that straddled political boundaries and defied geo-political divisions for generations create a skewed and unorthodox perspective on the Cold War and local histories entangled in it. The blending of domestic (Croatian) and diasporic (Croatian American) characters in his family vignettes contributes to a vernacular version of the global Cold War that is not easily contained by either of the ideological matrices, that of the free and democratic West or the communist and totalitarian East.

The appearance of his "socialist" grandmother, a proud U.S. citizen yet committed to social justice in the ambit of communist Yugoslavia (where she 
chooses not to stay), is an example of Novakovich's ironic juxtaposition that eschews standard political or historical taxonomies. The American grandmother, coming on rare occasions to visit her family, is walking proof of capitalism and its wily, seductive nature: not only does she bring commodities casually indicating the American materialist inclination (as the propaganda would have it) and its contagious affluence (as the narrator has it), but she is herself an assemblage of the ingenuity of American capitalism, with her dentures, wig, glasses, and other gadgets. The allure of America in a socialist country, however, is principally embodied in the emblematic image of money, the greenback $(P B, 25)$, whose abstract semantic is so universal that it encompasses the entire world: even if the grandson doesn't speak English all that well, the images on the dollar bill are easy to understand. In addition to the universal magic of the greenback, the other channel of capitalist infiltration is English. American pop culture, which enjoyed wide coverage in Yugoslavia after the thaw in relations in the 1950s, as well as general availability of English in public school instruction, made the communist country permeable to the presumably corrosive and corrupting influences of the West. The narrator's immersion in the English language is an equivalent of interior exile from his constraining situation as a Baptist in an atheist society and an individualist misfit in a system that promoted collectivism and bore down hard on dissent. Novakovich deliberately conjoins the totalitarian state, the Baptist church, and his father's sway over the family to create a backdrop against which to project his difference and provide an early motivation for his later exile, migration, and quest.

Novakovich's position as an exile (assuming just one role on a spectrum from political to economic positions) allows for a nuanced perspective of Yugoslavia and Croatia, on one hand, and the United States, on the other. However, let's zoom in on precisely the times that made history, the 1980s, which are for Novakovich marked by several homecoming travels to Croatia. When he got to Zagreb in the late 1980s, he states, it was hard for him to get a real picture $(P B, 73)$, meaning that, in Clifford's parlance, the experiential model no longer helps the author to establish and maintain textual authority. 
We ought to pose a question: why does the narrator feel that he can no longer cognitively and discursively master what used to be "homely" reality? One of the proposed answers might be that he finds himself in limbo precisely as designated by Raymond Williams's articulation of the residual and emergent cultural forms that compete and contend in the writer's vision. As he finds himself in Zagreb, he is baffled by the city even though he is not a stranger. For his Anglophone readers, he explains history at every turn and then provides a set of illustrative comparisons between Yugoslavia and the USSR, a reasonable strategy within the comprehensive Cold War paradigm that otherwise informs his writings. Still, as a baffled ethnographer (on cue from Clifford) Novakovich raises constantly questions pertaining to writing, the representation of social facts, narrative authority, heteroglossia, and cultural translation. The incipient break-up of his textual authority foreshadows (and we tend to retroactively inscribe this into the text by curtesy of later historical developments) dramatic political and social transformations just around the corner at the time of Novakovich's late-1980s visit. His perspective, due to his particular authorial position and thanks to the texts' peculiar generic features and capacities, remains one of the most acute and engaged statements on the waning and death of the socialist paradigm and the arrival of a new, transitional and capitalist paradigm not only in Croatian American but also in Croatian literature, to the extent that Novakovich is part of the latter (which we assume him to be).

My discussion has tried to advance and sustain the argument that a segment of literary production of Croatian and Croatian American diasporic writers (the distinctions were hard to maintain at times and irrelevant for the argument) are in a textual, generic, and thematic dialogue as they capture in the form of travelogue and other neo-documentary genres some aspects of continuing and multifaceted relations between socialist Croatia, democratic Croatia, and the United States. This brief look into what promises to be a much broader textual archive should encourage further explorations of the way Croatian and Croatian American diasporic literatures share the image repertoire, but also indicate points of divergence due to the facts of transna- 
tionalism, contact zones, heteroglossia, and cultural translation.

\section{Works Cited}

Ash, Timothy Garton. “1989!” The New York Review of Books. 5 November 2009. Web. 11 July 2016. <http://www.nybooks.com/articles/2009/11/05/1989/>

Belair, Felix. "Yugoslavia May Get Fulbright Scholars." New York Times Archive. 27 October 1964. Web. 10 June 2016. <http://www.nytimes.com/1964/10/27/yugoslaviamay-get-fulbright-scholars.html?_r=0>

Blažević, Neda Miranda. Američka predigra. Roman. Zagreb: Grafički zavod Hrvatske, 1989. Print.

Clifford, James. The Predicament of Culture: Twentieth-Century Ethnography, Literature, and Art. 1988. Cambridge, Mass. and London: Harvard UP, 1994. Print.

Crnković, Gordana P. "Have a Nice Day: From the Balkan War to the American Dream and the Things That Shape the Way We See Each Other." Ramet and Crnković 158-72.

Dedijer, Vladimir. Beleške iz Amerike. Beograd: Kultura, 1945. Print.

Denning, Michael. "The Laboring of American Culture." A Concise Companion to American Studies. Ed. John Carlos Rowe. Malden, MA and Oxford: Blackwell, 2010. 59-73. Print.

Drapac, Vesna. Constructing Yugoslavia: A Transnational History. Houndmills: Palgrave Macmillan, 2010. Print.

Dukić, Davor. "Predgovor: O imagologiji." Kako vidimo strane zemlje. Prir. Dukić et al. Zagreb: Srednja Europa, 2009. 5-22. Print.

Erll, Astrid. "Cultural Memory Studies: An Introduction." Cultural Memory Studies: An International and Interdisciplinary Handbook. Ed. Erll and Ansgar Nünning. Berlin and New York: Walter de Gruyter, 2008. 1-15. Print.

Fabrio, Nedjeljko. Vježbanje života: kronisterija. 1985. Zagreb: Profil international, 2005. Jakovina, Tvrtko. "Sloboda u raspadu: Nesvrstana, samoupravna; nestabilna i slaba SFRJ: od smrti Tita do uspona Miloševića." Kostelnik i Vukić 13-34.

Jelušić, Božica. Orkhak kontinenta. Zagreb: Globus, 1988. Print.

Koenen, Gerd. Što je bio komunizam? 2010. Zagreb: Durieux, 2011. Print.

Kostelnik, Branko i Feđa Vukić, ur. Osamdesete! Slatka dekadencija postmoderne. Zagreb: 
HDLU, DIPK, 2015. Print.

Lisle, Debbie. The Global Politics of Contemporary Travel Writing. Cambridge: Cambridge UP, 2006. Print.

Mazurkiewicz, Anna, ed. East Central Europe in Exile. Vol 2: Transatlantic Identities.

Newcastle upon Tyne: Cambridge Scholars Publishing, 2013. Print.

Meštrović, Stjepan G. Postemotional Society. London: Sage, 1997. Print.

Novakovich, Josip. Apricots from Chernobyl. Saint Paul: Graywolf P, 1995. Print.

--- . Plum Brandy: Croatian Journeys. Buffalo: White Pine P, 2003. Print.

--- . Shopping for a Better Country. Essays. Westland, MI: Dzanc Books, 2012. Print.

Pogačnik, Jagna. "Što je ostalo od književnosti osamdesetih? (Slučaj proza).” Kostelnik i Vukić 89-103.

Pratt, Mary Louise. Imperial Eyes: Travel Writing and Transculturation. 2nd ed. New York: Routledge, 2008. Print.

Ramet, Sabrina P. Balkan Babel: The Disintegration of Yugoslavia from the Death of Tito to the Fall of Milošević. Boulder, Col.: Westview P, 2002. Print.

Ramet, Sabrina P. and Gordana P. Crnković, eds. Kazaaam! splat! ploof! The American Impact on the European Popular Culture since 1945. Lanham: Rowman and Littlefield, 2003. Print.

Rugh, William A., ed. The Practice of Public Diplomacy: Confronting Challenges Abroad. New York: Palgrave Macmillan, 2011. Print.

Shapiro, Steven. The Culture and Commerce of the Early American Novel: Reading the Atlantic World-System. University Park: The Pennsylvania State UP, 2008. Print.

Šesnić, Jelena. "The Geo-political Imaginaries of Croatian American Diasporic Writers.” Twentieth-Century Literature. Forthcoming.

Thoreau, H.D. Walden. 1854. Web. 11 July 2016. <http://archive.vcu.edu/english/ engweb/transcendentalism/authors/thoreau/walden/>

Verdery, Katherine. What Was Socialism, and What Comes Next? Princeton: Princeton UP, 1996. Print. 